\title{
Planococcus columbae sp. nov., isolated from pigeon faeces
}

\author{
Correspondence \\ T. Chakrabarti \\ tapan@imtech.res.in
}

\author{
K. Suresh, S. Mayilraj, A. Bhattacharya and T. Chakrabarti \\ Microbial Type Culture Collection and Gene Bank (MTCC), Institute of Microbial Technology, \\ Sector 39A, Chandigarh 160 036, India
}

\begin{abstract}
An orange-pigmented, Gram-positive bacterial strain, designated $\mathrm{PgEx} 11^{\top}$, was isolated from pigeon faeces. Analysis of the $16 \mathrm{~S}$ rRNA gene sequence of the isolate indicated that it had 94.2-98.2\% sequence identity with respect to those of seven recognized species of the genus Planococcus. The strain $\mathrm{PgEx} 11^{\top}$ contained anteiso- $\mathrm{C}_{15: 0}$ as a major cellular fatty acid and MK-7 and MK-8 as the major menaquinones. The DNA G+C content of strain PgEx11 ${ }^{\top}$ was $50.5 \mathrm{~mol} \%$. Furthermore, analysis of the 16S rRNA gene sequence indicated high levels of similarity with Planococcus rifietoensis (98.2\%), Planococcus maitriensis (97.6\%), Planococcus citreus (97.5\%) and Planococcus maritimus (97.1\%). However, the mean value for DNA-DNA relatedness between $\mathrm{PgEx} 11^{\top}$ and these four closely related species was in the range 45.4-16.8\%, respectively. Moreover, strain PgEx $11^{\top}$ also differs from its close relatives with regard to biochemical and chemotaxonomic characteristics. On the basis of phenotypic, chemotaxonomic and genotypic differences, strain $\mathrm{PgEx} 11^{\top}$ represents a novel species of the genus Planococcus, for which the name Planococcus columbae sp. nov. is proposed. The type strain is $\operatorname{PgEx} 11^{\top}\left(=\right.$ MTCC $\left.7251^{\top}=\mathrm{DSM} 17517^{\top}\right)$.
\end{abstract}

Members of the genus Planococcus have been isolated from diverse environments, such as seawater (Yoon et al., 2003), sediments (Romano et al., 2003), soil (Kocur et al., 1970; Mayilraj et al., 2005), cyanobacterial mats (Reddy et al., 2002; Alam et al., 2003) and fish (Hao \& Komagata, 1985). The genus Planococcus was proposed by Migula (1894) to accommodate Gram-positive, aerobic, motile cocci. This genus is currently placed within the family Planococcaceae in the phylum Firmicutes. Other genera belonging to this family are Filibacter, Kurthia, Planomicrobium and Sporosarcina. The type species of the genus is Planococcus citreus. However, on the basis of phenotypic and phylogenetic analyses, a few species of this genus were transferred to the genus Planomicrobium (Yoon et al., 2001; Dai et al., 2005) and Planococcus halophilus was reclassified as Marinococcus halophilus (Hao et al., 1984). In the present communication, we describe the characterization, using a polyphasic approach, of a novel strain isolated from pigeon faeces and which we propose as a novel species of the genus Planococcus.

The GenBank/EMBL/DDBJ accession number for the 16S rRNA gene sequence of strain $\mathrm{PgEx} 11^{\top}$ is AJ966515.

Differential phenotypic and chemotaxonomic characteristics for strain $\mathrm{PgEx} 11^{\top}$ with respect to species of the genera Planococcus and Planomicrobium are shown in a supplementary table available with the online version of this paper.
The bacterium PgEx $11^{\mathrm{T}}$ was isolated from pigeon faeces by dilution-plating samples on nutrient agar (Himedia) and incubating the plates at $30{ }^{\circ} \mathrm{C}$ for $24 \mathrm{~h}$. The dried surface of the faeces was washed with sterile $0.1 \mathrm{mM}$ phosphate buffer ( $\mathrm{pH}$ 7.2) and the core was used to make a suspension in the same buffer. An orange-pigmented colony was isolated, purified and preserved for further characterization. Reference strains Planococcus citreus JCM 2532 ${ }^{\mathrm{T}}$ and Planococcus maritimus JCM $11543^{\mathrm{T}}$ were obtained from the Japan Collection for Micro-organisms (Saitama, Japan), Planococcus rifietoensis DSM $15069^{\mathrm{T}}$ was obtained from the Deutsche Sammlung von Mikroorganismen und Zellkulturen (Braunschweig, Germany) and Planococcus maitriensis MTCC $4827^{\mathrm{T}}$ was obtained from the Microbial Type Culture Collection and Gene Bank (Chandigarh, India). The cell morphology of strain $\operatorname{PgEx} 11^{\mathrm{T}}$ was observed by using phase-contrast microscopy (Axiophot; Zeiss) with an oil-immersion objective $(\times 100)$. Physiological tests were performed using nutrient agar medium. For the various biochemical tests mentioned in the species description, the culture was grown at $30^{\circ} \mathrm{C}$ in nutrient broth (Himedia). Catalase and oxidase tests were performed according to Cowan \& Steel (1965). The following determinations were performed as described by Lanyi (1987): the hydrolysis of aesculin, the indole test, the Voges-Proskauer test, the methyl red test, $\mathrm{H}_{2} \mathrm{~S}$ production, and nitrate reduction. The utilization of various carbon compounds and the hydrolysis of casein, gelatin, starch and Tween 20 were determined by 
following standard methods (Smibert \& Krieg, 1994). The ability of $\operatorname{PgEx} 11^{\mathrm{T}}$ to utilize various carbon compounds as sole carbon sources was checked as described previously (Suresh et al., 2006). Antibiotic discs (Himedia) placed on tryptone soya agar were used to determine the sensitivity of PgEx $11^{\mathrm{T}}$ to various antibiotics. Strain $\operatorname{PgEx} 11^{\mathrm{T}}$ comprises motile, aerobic, Gram-positive, catalase-positive cocci; other phenotypic and chemotaxonomic characteristics are given in the species description and in Table 1.

For cellular fatty acid analyses, cells were grown on nutrient agar with $4 \% \mathrm{NaCl}$ at $30^{\circ} \mathrm{C}$ for $24 \mathrm{~h}$; the fatty acid methyl esters were extracted (Sato \& Murata, 1988) and analysed using the Microbial Identification System (MIDI) as described by Pandey et al. (2002). Isoprenoid quinones and polar lipids were extracted and analysed according to the methods described by Minnikin et al. (1984). Peptidoglycan was prepared and analysed according to the method described by Komagata \& Suzuki (1987). The G + C content (mol\%) of genomic DNA was estimated spectrophotometrically (Lambda 35; Perkin Elmer) as described by Mandel \& Marmur (1968). DNA-DNA hybridization was performed by using the membrane filter method (Tourova \& Antonov, 1987) as described by Shivaji et al. (1992).

The fatty acid profile of strain $\operatorname{PgEx} 11^{\mathrm{T}}$ was similar to those of members of the genus Planococcus and contained iso$\mathrm{C}_{15: 0}$ and anteiso- $\mathrm{C}_{15: 0}$ as the major fatty acids (Table 2 ). The polar lipids found in strain $\operatorname{PgEx} 11^{\mathrm{T}}$ were phosphatidylglycerol, diphosphatidylglycerol and phosphatidylcholine, which were also reported for members of the genus Planococcus. In addition, strain $\operatorname{PgEx} 11^{\mathrm{T}}$ contained phosphatidylinositol, an unknown glycolipid and two unknown phospholipids. The peptidoglycan cross-link peptide in strain PgEx $11^{\mathrm{T}}$ was L-Lys-D-Glu (classified as the A4 $\alpha$ type by Schleifer \& Kandler, 1972).

Table 1. Differential phenotypic and chemotaxonomic characteristics of strain $\mathrm{PgEx} 11^{\top}$ with respect to closely related species

Taxa: 1, strain $\operatorname{PgEx} 11^{\mathrm{T}}$ (data from present study); 2, Planococcus rifietoensis (Romano et al., 2003; present study); 3, Planococcus maritimus (Yoon et al., 2003; present study); 4, Planococcus maitriensis (Alam et al., 2003; present study); 5, Planococcus citreus (Hao \& Komagata, 1985; present study); 6, Planococcus kocurii (Hao \& Komagata, 1985); 7, Planomicrobium koreense (Yoon et al., 2001); 8, Planomicrobium okeanokoites (Nakagawa et al., 1996; Yoon et al., 2001); 9, Planomicrobium mcmeekinii (Junge et al., 1998; Yoon et al., 2001). +, Present; - , absent; w, weakly positive; NR, not reported.

\begin{tabular}{|c|c|c|c|c|c|c|c|c|c|}
\hline Characteristic & 1 & 2 & 3 & 4 & 5 & 6 & 7 & 8 & 9 \\
\hline \multicolumn{10}{|l|}{ Growth at: } \\
\hline $42{ }^{\circ} \mathrm{C}$ & + & + & - & - & - & - & - & - & - \\
\hline Oxidase & + & + & - & - & - & - & - & $\mathrm{w}$ & - \\
\hline \multicolumn{10}{|l|}{ Hydrolysis of: } \\
\hline Tween 20 & + & - & - & - & - & $\mathrm{NR}$ & $\mathrm{NR}$ & $\mathrm{NR}$ & NR \\
\hline Tween 40 & + & + & - & - & + & $\mathrm{NR}$ & $\mathrm{NR}$ & $\mathrm{NR}$ & $\mathrm{NR}$ \\
\hline Gelatin & - & + & $-{ }^{*}$ & $-\dagger$ & + & + & + & + & + \\
\hline Citrate utilization & - & + & - & $-\dagger$ & + & $\mathrm{NR}$ & $\mathrm{NR}$ & $\mathrm{NR}$ & NR \\
\hline Nitrate reduction & + & - & - & + & - & - & - & - & + \\
\hline Fructose & - & - & $-^{*}$ & + & - & NR & - & + & + \\
\hline Mannose & - & - & $+^{*}$ & + & - & $\mathrm{NR}$ & - & $\mathrm{NR}$ & NR \\
\hline Sucrose & + & - & - & W & + & NR & - & - & NR \\
\hline Peptidoglycan type & $\begin{array}{c}\text { L-Lys-D- } \\
\text { Glu }\end{array}$ & $\begin{array}{c}\text { L-Lys-D- } \\
\text { Glu }\end{array}$ & $\begin{array}{c}\text { L-Lys-D- } \\
\text { Glu }\end{array}$ & $\begin{array}{c}\text { L-Lys-D- } \\
\text { Glu }\end{array}$ & $\begin{array}{c}\text { L-Lys-D- } \\
\text { Glu }\end{array}$ & $\begin{array}{c}\text { L-Lys-D- } \\
\text { Glu }\end{array}$ & $\begin{array}{c}\text { L-Lys-D- } \\
\text { Glu }\end{array}$ & $\begin{array}{c}\text { L-Lys-D- } \\
\text { Asp }\end{array}$ & $\begin{array}{c}\text { L-Lys-D- } \\
\text { Asp }\end{array}$ \\
\hline Menaquinones & $\begin{array}{c}\text { MK-7, } \\
\text { MK-7 }\left(\mathrm{H}_{2}\right), \\
\text { MK-8 }\end{array}$ & MK-8 & $\begin{array}{l}\text { MK-6, } \\
\text { MK-7, } \\
\text { MK-8 }\end{array}$ & $\begin{array}{l}\text { MK-7, } \\
\text { MK-8 }\end{array}$ & $\begin{array}{l}\text { MK-6, } \\
\text { MK-7, } \\
\text { MK-8 }\end{array}$ & $\begin{array}{l}\text { MK-7, } \\
\text { MK-8 }\end{array}$ & $\begin{array}{l}\text { MK-6, } \\
\text { MK-7, } \\
\text { MK-8 }\end{array}$ & $\begin{array}{l}\text { MK-7, } \\
\text { MK-8 }\end{array}$ & $\begin{array}{l}\text { MK-7, } \\
\text { MK-8 }\end{array}$ \\
\hline
\end{tabular}

${ }^{\star}$ Data differed from that in Yoon et al. (2003).

$\dagger$ Data differed from that in Alam et al. (2003). 
Table 2. Fatty acid contents (\%) of strain $\mathrm{PgEx} 11^{\top}$ and five closely related species of Planococcus and three of Planomicrobium

Taxa: 1, strain $\operatorname{PgEx}_{1}{ }^{\mathrm{T}}$ (data from present study); 2, Planococcus rifietoensis (present study); 3, Planococcus maritimus (present study); 4, Planococcus maitriensis (present study); 5, Planococcus citreus (present study); 6, Planococcus kocurii (Yoon et al., 2001); 7, Planomicrobium koreense (Yoon et al., 2001); 8, Planomicrobium okeanokoites (Yoon et al., 2001); 9, Planomicrobium mcmeekinii (Yoon et al., 2001). -, Absent; NR, not reported.

\begin{tabular}{|c|c|c|c|c|c|c|c|c|c|}
\hline Fatty acid methyl ester & $1^{*}$ & $2^{*}$ & $3^{*}$ & $4^{\star}$ & $5^{\star}$ & $6 \dagger$ & $7 \dagger$ & $8 \dagger$ & $9 \dagger$ \\
\hline iso- $\mathrm{C}_{14: 0}$ & 10.5 & 5.1 & 2.1 & 2.4 & 9.4 & 13.1 & 21.0 & 40.4 & 18.1 \\
\hline iso- $\mathrm{C}_{15: 0}$ & 25.2 & 18.1 & 23.0 & 5.3 & 6.7 & 5.1 & 6.4 & NR & 5.3 \\
\hline anteiso- $\mathrm{C}_{15: 0}$ & 35.1 & 43.7 & 38.0 & 31.4 & 45.7 & 40.9 & 26.1 & 4.0 & 32.0 \\
\hline $\mathrm{C}_{16: 1} \omega 7 c \mathrm{OH}$ & 4.7 & 4.3 & 3.3 & 2.6 & - & 11.4 & 23.6 & 26.1 & 22.9 \\
\hline $\mathrm{C}_{16: 1} \omega 9 c$ & - & - & - & 5.2 & - & NR & NR & NR & NR \\
\hline $\mathrm{C}_{16: 1} \omega 11 c$ & - & - & 0.6 & 0.3 & 9.8 & 2.5 & 1.7 & 2.1 & 2.3 \\
\hline iso- $\mathrm{C}_{16: 0}$ & 11.5 & 9.3 & 4.1 & 9.2 & 8.6 & 7.2 & 11.1 & 24.5 & 8.7 \\
\hline $\mathrm{C}_{16: 0}$ & 1.5 & 2.8 & 4.5 & 6.8 & 19.6 & 1.4 & NR & 1.1 & NR \\
\hline iso- $\mathrm{C}_{17: 0}$ & 5.0 & 8.8 & 7.6 & - & - & 1.7 & 1.6 & NR & 1.3 \\
\hline anteiso- $\mathrm{C}_{17: 0}$ & 4.3 & 7.6 & 7.0 & 7.2 & - & 2.6 & 1.6 & NR & 1.2 \\
\hline $\mathrm{C}_{17: 0}$ & 1.8 & - & - & 4.5 & - & NR & NR & NR & NR \\
\hline iso- $\mathrm{C}_{17: 1} \omega 10 c$ & - & - & 4.5 & - & - & 2.5 & 1.9 & NR & 2.4 \\
\hline Summed feature $4 \ddagger$ & - & - & 3.1 & - & - & 4.5 & NR & NR & 3.0 \\
\hline
\end{tabular}

${ }^{*}$ Strains were grown on nutrient agar with $4 \% \mathrm{NaCl}$ at a temperature of $30^{\circ} \mathrm{C}$ for $24 \mathrm{~h}$.

$\dagger$ Strains were grown on marine agar (data from Yoon et al., 2001).

$\ddagger$ Summed feature 4 consists of $\mathrm{C}_{17: 1}$ iso $\mathrm{I} /$ anteiso $\mathrm{B}$, which could not be separated by MIDI.

The 16S rRNA gene was amplified by using a PCR with primers 8-27f ( $5^{\prime}$-AGAGTTTGATCCTGGCTCAG$\left.3^{\prime}\right)$ and 1492r (5'-TACGGYTACCTTGTTACGACTT-3') as described by Pandey et al. (2002). The PCR product was purified using a QIAquick PCR purification kit (Qiagen). Purified amplicon was sequenced using a BigDye terminator cycle sequencing kit and an ABI PRISM model 3130xl automatic DNA sequencer (Applied Biosystems). The sequence of the 16S rRNA gene (a $1481 \mathrm{bp}$ continuous stretch) was aligned with closely related sequences using CLUSTAL_X (Thompson et al., 1997) and was edited manually. Phylogenetic distances were calculated using the Kimura two-parameter model (Kimura, 1980) and trees were constructed using the neighbour-joining and UPGMA methods in the PHYLIP package (Felsenstein, 1993). A phylogenetic tree was also constructed using TREECON (version 1.3b) (Van de Peer \& De Wachter, 1997). The stability of the tree was assessed by performing 1000 replicates. Paenibacillus polymyxa (X60632) was used as an outgroup.

Analysis of the $16 \mathrm{~S}$ rRNA gene sequence of strain PgEx $11^{\mathrm{T}}$ indicated that it is closely related to Planococcus rifietoensis DSM $15069^{\mathrm{T}}$ (98.2\% identity); it exhibited lower levels of identity with respect to Planococcus species such as Planococcus maitriensis MTCC $4827^{\mathrm{T}}$ (97.6\%), Planococcus citreus NCIMB $1493^{\mathrm{T}}(97.5 \%)$, Planococcus maritimus KCCM $41587^{\mathrm{T}}(97.1 \%)$, Planococcus kocurii $(95.0 \%)$ and Planococcus stackebrandtii MTCC $6226^{\mathrm{T}}$ (94.2\%). It showed less than $96 \%$ sequence similarity with respect to species of the genus Planomicrobium. Strain PgEx $11^{\mathrm{T}}$ formed a cluster with the species showing 16S rRNA gene sequence similarity levels above $97 \%$ (Fig. 1). A phylogenetic tree constructed using UPGMA also yielded a similar stable grouping. Strain PgEx $11^{\mathrm{T}}$ exhibited the presence of the nucleotides T and A at positions 183 and 190 (according to Escherichia coli numbering) in the 16S rRNA gene; these were described as signature nucleotides for Planococcus by Dai et al. (2005) differentiating members of that genus from members of the genus Planomicrobium.

The levels of genomic relatedness between strain PgEx $11^{\mathrm{T}}$ and four closely related species of the genus Planococcus, namely Planococcus rifietoensis, Planococcus maitriensis, Planococcus citreus and Planococcus maritimus (showing 16S rRNA gene sequence similarities between 98.2 and $97.1 \%$ ), were $45.4,42.7,27.8$ and $16.8 \%$, respectively. It is generally accepted that at more than $3 \%$ dissimilarity in the 16S rRNA gene sequences, other species of the genus can be excluded from DNA-DNA hybridization (Stackebrandt \& Goebel, 1994). Moreover, although the cellular fatty acid composition and cell-wall peptidoglycan of strain PgEx $11^{\mathrm{T}}$ are similar to those of members of the genus Planococcus, the cellular polar lipid profile and menaquinone composition differ (Table 1).

We have examined our data for strain PgEx $11^{\mathrm{T}}$, Planococcus rifietoensis, Planococcus maritimus, Planococcus maitriensis and Planococcus citreus and other workers' data for different species of Planococcus and for members of the genus 


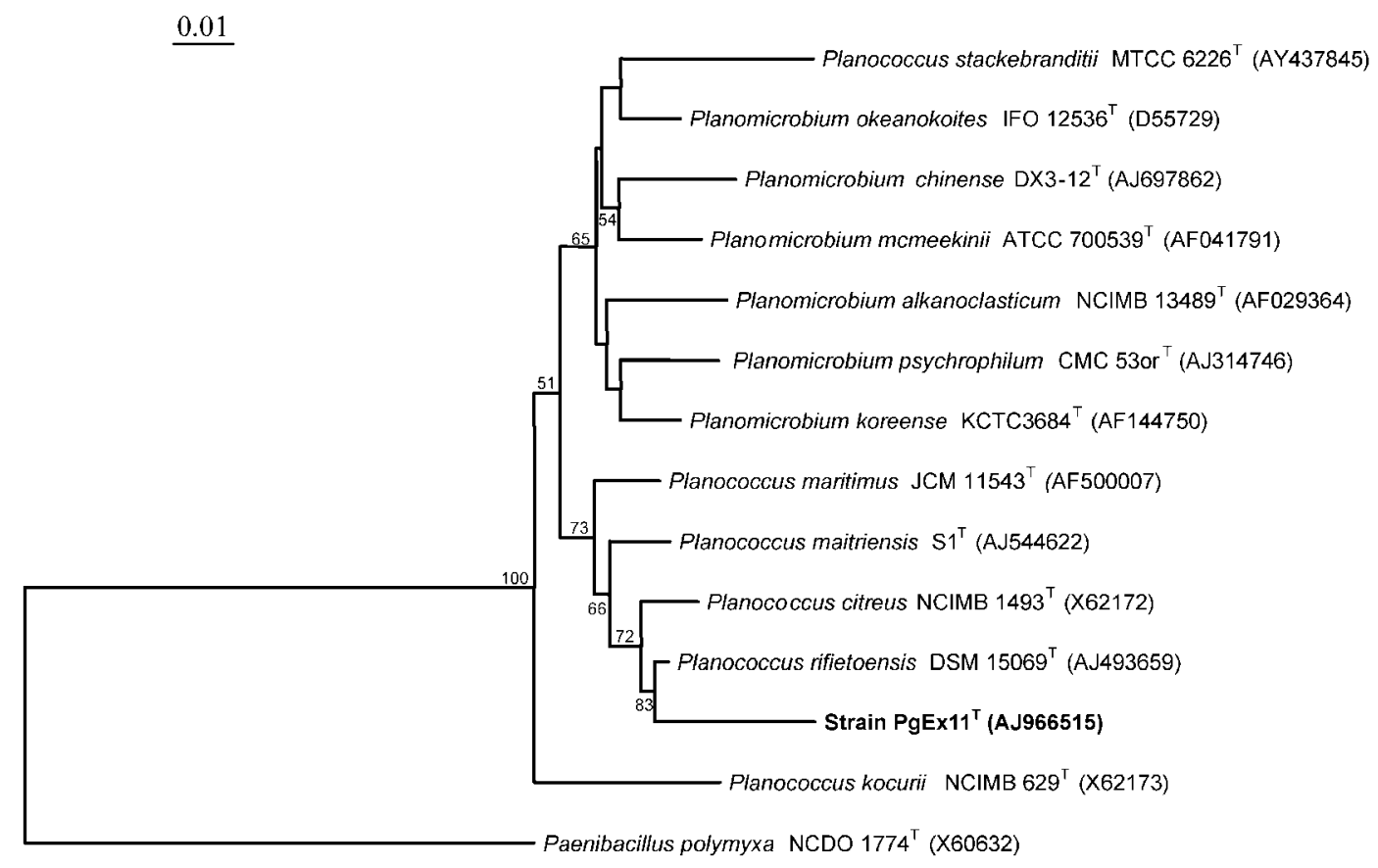

Fig. 1. Neighbour-joining phylogenetic tree, based on $16 \mathrm{~S}$ rRNA gene sequences, showing the relationship between strain $\mathrm{PgEx} 11^{\top}$ and related species of the genera Planococcus and Planomicrobium. Bootstrap values greater than $50 \%$ (based on 1000 replicates) are given at the nodes. Bar, 0.01 substitutions per site.

Planomicrobium (see Supplementary Table S1, available in IJSEM Online). On the basis of this comparative analysis of phenotypic, chemotaxonomic and phylogenetic characteristics, we came to the conclusion that the creation of the genus Planomicrobium cannot be justified. The genera Planococcus and Planomicrobium cannot be distinguished on the basis of phenotypic characteristics. Some species of Planococcus share characteristics mentioned in the description of the genus Planomicrobium (Yoon et al., 2001). Casein hydrolysis is negative for Planomicrobium psychrophilum and Planomicrobium chinense, but is positive in the genus description. Similarly, starch is hydrolysed in Planomicrobium alkanoclasticum, but is negative in the genus description. The only features common to the species of the genus Planomicrobium are the presence of signature nucleotides $\mathrm{C}$ and $G$ at positions 183 and 190 (Dai et al., 2005).

Phylogenetically, the species of the genus Planomicrobium clusters with the genus Planococcus. The peptidoglycan cross-link is L-Lys-D-Glu in both genera, with the exception of two Planomicrobium species, in which it is L-Lys-D-Asp. In fact, the type species of Planomicrobium, Planomicrobium koreense, has the same peptidoglycan as all other Planococcus species. Menaquinones MK-7 and MK-8 are present in all species of Planococcus and Planomicrobium. The polar lipids in Planomicrobium species, phosphatidylethanolamine, phosphatidylglycerol and diphosphatidylglycerol, are also not unique to that genus because they are also present in at least four species of the genus Planococcus. The cellular fatty acid profiles of the species of these two genera do not exhibit any qualitative differences with respect to each other. In addition, the DNA G $+\mathrm{C}$ contents (mol\%) do not show a clear demarcation distinguishing the species of Planococcus from those of the genus Planomicrobium.

The taxonomic status of the genus Planomicrobium should therefore be revisited. We strongly feel that the species removed from the genus Planococcus should be reinstated and that the type species of the genus Planomicrobium, Planomicrobium koreense, should be considered as a species of the genus Planococcus.

On the basis of phenotypic, chemotaxonomic and phylogenetic characteristics, strain $\operatorname{PgEx} 11^{\mathrm{T}}$ represents a novel species of the genus Planococcus, for which the name Planococcus columbae sp. nov. is proposed.

\section{Description of Planococcus columbae sp. nov.}

Planococcus columbae (co.lum'ba.e. L. gen. n. columbae of a pigeon Columba livia).

The cells of PgEx $11^{\mathrm{T}}$ are aerobic, Gram-positive cocci, motile, non-sporulating and $0.8-1.0 \mu \mathrm{m}$ in size. Colonies on nutrient agar are orange, circular, entire, smooth, convex and $1.0-2.0 \mathrm{~mm}$ in diameter. Strain $\operatorname{PgEx} 11^{\mathrm{T}}$ grows at temperatures between 8 and $42{ }^{\circ} \mathrm{C}$ (optimum, $30^{\circ} \mathrm{C}$ ) but not at $4{ }^{\circ} \mathrm{C}$, and grows at $\mathrm{pH} 6.0-11.0$ (optimum, $\mathrm{pH}$ 7.0-8.0). Growth is observed between 0 and $14 \% \mathrm{NaCl}$ (optimum, 4-5\%). Positive for catalase, but negative for amylase, protease and arginine dihydrolase. Does not hydrolyse urea 
or aesculin. Negative in the methyl red test, in the test for indole production, in the Voges-Proskauer test and for $\mathrm{H}_{2} \mathrm{~S}$ production. Utilizes D-arabitol, L-arabinose, carboxymethylcellulose, D-cellobiose, dulcitol, D-glucose, D-galactose, D-fucose, inulin, lactose, melezitose, D-maltose, D-mannitol, D-mannose, D-ribose, L-rhamnose, $\mathrm{N}$-acetylglucosamine, sodium acetate, starch, sucrose, xylan and Dxylose but not D-malic acid. Does not produce acid from glucose, galactose, inulin, $i$-inositol, lactose, raffinose, salicin, sorbitol or trehalose. Other phenotypic characteristics are shown in Table 1. Resistant to penicillin (1.5 U), cephaloridine $(30 \mu \mathrm{g})$ and tobramycin $(10 \mu \mathrm{g})$, but sensitive to rifampicin $(5 \mu \mathrm{g})$, gentamicin $(10 \mu \mathrm{g})$, neomycin $(30 \mu \mathrm{g})$, streptomycin $(25 \mu \mathrm{g})$ and chlortetracycline $(30 \mu \mathrm{g})$. Major fatty acids are anteiso- $\mathrm{C}_{15: 0}(35.1 \%)$, iso- $\mathrm{C}_{15: 0}(25.2 \%)$, iso- $\mathrm{C}_{16: 0}(11.5 \%)$ and $\mathrm{C}_{14: 0}(10.5 \%)$. Cell-wall peptidoglycan is L-Lys-D-Glu. The menaquinones found in strain PgEx $11^{\mathrm{T}}$ are MK-7 $(48 \%)$, MK-8 $(35 \%)$ and MK-7 $\left(\mathrm{H}_{2}\right)$ $(22 \%)$. The DNA G $+\mathrm{C}$ content is $50.5 \mathrm{~mol} \%$.

The type strain, $\operatorname{PgEx} 11^{\mathrm{T}}\left(=\right.$ MTCC $\left.7251^{\mathrm{T}}=\operatorname{DSM} 17517^{\mathrm{T}}\right)$, was isolated from pigeon faeces.

\section{Acknowledgements}

We would like to thank Mr Deepak Bhat (IMTECH), for his help with DNA sequencing, and Ms Gabi Poetter (Deutsche Sammlung von Mikroorganismen und Zellkulturen) for her help with some chemotaxonomic analyses. This work was supported by the Department of Biotechnology (DBT), Government of India and Council of Scientific and Industrial Research (CSIR). A. B. is a recipient of a CSIR fellowship. This is IMTECH communication number 37/2006.

\section{References}

Alam, S. I., Singh, L., Dube, S., Reddy, G. S. N. \& Shivaji, S. (2003). Psychrophilic Planococcus maitriensis sp. nov. from Antarctica. Syst Appl Microbiol 26, 505-510.

Cowan, S. T. \& Steel, K. J. (1965). Manual for the Identification of Medical Bacteria. London: Cambridge University Press.

Dai, X., Wang, Y.-N., Wang, B.-J., Liu, S.-J. \& Zhou, Y.-G. (2005). Planomicrobium chinense sp. nov., isolated from coastal sediment, and transfer of Planococcus psychrophilus and Planococcus alkanoclasticus to Planomicrobium as Planomicrobium psychrophilum comb. nov. and Planomicrobium alkanoclasticum comb. nov. Int J Syst Evol Microbiol 55, 699-702.

Felsenstein, J. (1993). PHYLIP (phylogeny inference package), version 3.5c. Department of Genome Sciences, University of Washington, Seattle, USA.

Hao, M. V. \& Komagata, K. (1985). A new species of Planococcus, $P$. kocurii isolated from fish, frozen foods, and fish curing brine. J Gen Appl Microbiol 31, 441-455.

Hao, M. V., Kocur, M. \& Komagata, K. (1984). Marinococcus gen. nov., a new genus for motile cocci with meso-diaminopimelic acid in the cell wall; and Marinococcus albus sp. nov. and Marinococcus halophilus Novitsky and Kushner comb. nov. J Gen Appl Microbiol 30, 449-459.

Junge, K., Gosink, J. J., Hoppe, H.-G. \& Staley, J. T. (1998). Arthrobacter, Brachybacterium and Planococcus isolates identified from Antarctic sea ice brine. Description of Planococcus mcmeekinii, sp. nov. Syst Appl Microbiol 21, 306-314.
Kimura, M. (1980). A simple method for estimating evolutionary rates of base substitutions through comparative studies of nucleotide sequences. J Mol Evol 16, 111-120.

Kocur, M., Pacova, Z., Hodgkiss, W. \& Martinec, T. (1970). The taxonomic status of the genus Planococcus Migula 1894. Int J Syst Bacteriol 20, 241-248.

Komagata, K. \& Suzuki, K. I. (1987). Lipid and cell wall analysis in bacterial systematics. Methods Microbiol 19, 161-206.

Lanyi, B. (1987). Classical and rapid identification methods for medically important bacteria. Methods Microbiol 19, 1-67.

Mandel, M. \& Marmur, J. (1968). Use of ultraviolet absorbancetemperature profile for determining the guanine plus cytosine content of DNA. Methods Enzymol 12B, 195-206.

Mayilraj, S., Prasad, G. S., Suresh, K., Saini, H. S., Shivaji, S. \& Chakrabarti, T. (2005). Planococcus stackebrandtii sp. nov., isolated from a cold desert of the Himalayas, India. Int J Syst Evol Microbiol 55, 91-94.

Migula, W. (1894). Uber ein neues system der bacterien. Arb Bakteriol Inst Karlsruhe 1, 235-238.

Minnikin, D. E., O'Donnell, A. G., Goodfellow, M., Alderson, G., Athalye, M., Schaal, K. \& Parlett, J. H. (1984). An integrated procedure for the extraction of bacterial isoprenoid quinones and polar lipids. J Microbiol Methods 2, 233-241.

Nakagawa, Y., Sakane, T. \& Yokota, A. (1996). Emendation of the genus Planococcus and transfer of Flavobacterium okeanokoites Zobell and Upham 1944 to the genus Planococcus as Planococcus okeanokoites comb. nov. Int J Syst Bacteriol 46, 866-870.

Pandey, K. K., Mayilraj, S. \& Chakrabarti, T. (2002). Pseudomonas indica sp. nov., a novel butane-utilizing species. Int J Syst Evol Microbiol 52, 1559-1567.

Reddy, G. S. N., Prakash, J. S. S., Vairamani, M., Prabhakar, S., Matsumoto, G. I. \& Shivaji, S. (2002). Planococcus antarcticus and Planococcus psychrophilus spp. nov., isolated from cyanobacterial mat samples collected from ponds in Antarctica. Extremophiles 6, 253-261.

Romano, I., Giordano, A., Lama, L., Nicolaus, B. \& Gambacorta, A. (2003). Planococcus rifietoensis sp. nov., isolated from algal mat collected from a sulfurous spring in Campania (Italy). Syst Appl Microbiol 26, 357-366.

Sato, N. S. \& Murata, N. (1988). Membrane lipids. Methods Enzymol 167, 251-259.

Schleifer, K. H. \& Kandler, O. (1972). Peptidoglycan types of bacterial cell walls and their taxonomic implications. Bacteriol Rev 36, 407-477.

Shivaji, S., Ray, M. K., Saisree, L., Jagannadham, M. V., Seshu Kumar, G., Reddy, G. S. N. \& Bhargava, P. M. (1992). Sphingobacterium antarcticus sp. nov. a psychrotrophic bacterium from the soils of Schirmacher Oasis, Antarctica. Int J Syst Bacteriol 42, 102-116.

Smibert, R. M. \& Krieg, N. R. (1994). Phenotypic characterization. In Methods for General and Molecular Bacteriology, pp. 607-654. Edited by P. Gerhardt. Washington, DC: American Society for Microbiology.

Stackebrandt, E. \& Goebel, B. M. (1994). Taxonomic note: a place for DNA-DNA reassociation and $16 \mathrm{~S}$ rRNA sequence analysis in the present species definition in bacteriology. Int J Syst Bacteriol 44, 846-849.

Suresh, K., Mayilraj, S. \& Chakrabarti, T. (2006). Effluviibacter roseus gen. nov., sp. nov., isolated from muddy water, belonging to the family "Flexibacteraceae". Int J Syst Evol Microbiol 56, 1703-1707.

Thompson, J. D., Gibson, T. J., Plewniak, F., Jeanmougin, F. \& Higgins, D. G. (1997). The CLUSTAL_X windows interface: flexible 
strategies for multiple sequence alignment aided by quality analysis tools. Nucleic Acids Res 25, 4876-4882.

Tourova, T. P. \& Antonov, A. S. (1987). Identification of microorganisms by rapid DNA-DNA hybridization. Methods Microbiol 19, 333-355.

Van de Peer, Y. \& De Wachter, R. (1997). Construction of evolutionary distance trees with TREECON for Windows: accounting for variation in nucleotide substitution rate among sites. Comput Appl Biosci 13, 227-230.
Yoon, J.-H., Kang, S.-S., Lee, K.-C., Lee, E. S., Kho, Y. H., Kang, K. H. \& Park, Y.-H. (2001). Planomicrobium koreense gen. nov., sp. nov., a bacterium isolated from the Korean traditional fermented seafood jeotgali, and transfer of Planococcus okeanokoites (Nakagawa et al. 1996) and Planococcus momeekinii (Junge et al. 1998) to the genus Planomicrobium. Int J Syst Evol Microbiol 51, 1511-1520.

Yoon, J.-H., Weiss, N., Kang, K. H., Oh, T. \& Park, Y.-H. (2003).

Planococcus maritimus sp. nov., isolated from sea water of a tidal flat in Korea. Int J Syst Evol Microbiol 53, 2013-2017. 